\title{
DEVELOPMENT LAND LEVELER TO SUIT SOIL INITIALIZE FOR CLOVER CROP
}

\author{
Fouda. O. $\mathbf{A}^{(*)}$ \\ M. A. Awad ${ }^{(*)}$ \\ Sh. F. Abd Elhamed ${ }^{(* *)}$
}

\begin{abstract}
Efforts were identified to improve seedbed for clover seed germination by adding till shares at the front of the land leveler blade. The studied variables are three share depths of 0.0, 50.0, $100.0 \mathrm{~mm}$ and three shares span of 118, 154 and $200 \mathrm{~mm}$ and four forward speeds of 2.7, 3.7, 4.3 and $4.9 \mathrm{~km} / \mathrm{h}$. The results indicated that, both of uprooting rice roots and planting intensity increased by 49.36, 27.55 also clover yield increased by $20.49 \%$. Tractor slippage was within safe limits by proportion of $11.76 \%$, pulling force of $2.67 \mathrm{kN}$, specific energy of $12.03 \mathrm{~kW} \mathrm{h/fed} \mathrm{and} \mathrm{the} \mathrm{mean}$ weight diameters of $28 \mathrm{~mm}$ at using the cutting blade of land leveler provided with share depth of $50 \mathrm{~mm}$, shares span of $118 \mathrm{~mm}$ and forward speed of $3.7 \mathrm{~km} / \mathrm{h}$. The developed land leveler at the previous operating conditions achieved the highest productivity of $59.6 \mathrm{Mg} / \mathrm{fe}$ from the total cutting time.
\end{abstract}

\section{INTRODUCTION}

Tn Egypt clover (Medicago sativa) is the most important crop. It considered as first green forage crops and its cultivated area is about 1.908 million feddan to produce $50405 \mathrm{Mg}$ yearly (Ministry of Agriculture and Land Reclamation, 2012). Usually, sowing directly after harvesting rice as zero tillage. Nevertheless, not gave maximize of clover crop in quality per cropping time. These disadvantages may be due to;

1. Rumanians water during rice planting (90 - 120 days) cause to cover soil surface with green algae.

2. Increase the soil compaction after during the rice harvesting by combine.

3. The lifting root of rice after harvesting obstruct the clover seed growing.

4. High remaining residues of rice straw in the soil after harvesting leads to obstruction first cutting of clover crop.

\footnotetext{
* Researcher in Agric. Eng. Res. Institute, Dokki, Giza, Egypt ** Senior researcher in Agric. Eng. Res. Institute, Dokki, Giza, Egypt
} 
Therefore, before sowing seeds, it is necessary to create a suitable seedbed for good seed germination. Thus, a correct seedbed will ensure the adequate moisture, air quantities and soil bed needed by clover plant. Land leveling saves irrigation water facilitates field operation, and increases yield (Rickman, 2002). In fact, research has shown that land leveling can increase crop yields by as much as 25 to $35 \%$, to improved water distribution and nutrient utilization. Studies indicated a significant (20 - 25\%) amount of irrigation water is lost during its application at the farm due to bad soil roughness and unevenness of the field (Cook and Peikert, 1960).

Most of reports indicated that, seedbed evaluated not only by the implements used, but also by the resulting soil properties. To obtain optimum yield of clover, available soil moisture in between $40-60 \%$ depletion of available water soil (Mahrous et al., 1984). Michael (1990) indicated that land leveling increased coefficient of useful time, field capacity and germination capacity as compared with unleveled land. Also, it, increased harvesting machine performance. El-Sayed et al. (1988) concluded that; tillage treatment reduced soil penetration resistance at surface layer by $33.33 \%$ for chiseling twice, and 58\% for harrowing twice after chiseling. The suitable seedbed for drilling must contain different aggregate size with diameters not greater than $50 \mathrm{~mm}$. The percentage of greater aggregates $(20-50 \mathrm{~mm})$ and the smallest $(<2 \mathrm{~mm})$ were kept to a minimum value of total aggregates (Abo-Habaga, 1992). Machine wheel track consider one of the most important factor of soil compaction and consequently crop yield. The highest soil penetration resistance was recorded at wheel track between $100-200 \mathrm{~mm}$ depth (Abo Habaga, 2000). Zayed (2010) cleared that the higher mean weight diameter value, 14.78 and $14.23 \mathrm{~mm}$, at $0.03 \%$ slope compared to that small mean weight diameter, 12.7 and $13.07 \mathrm{~mm}$, at zero level. It was better soil pulverization because adding developed unit (adding chisel plow shares) of the laser scraper. He added that drawbar power increased with the increase of forward speed at 3.45, 4.19, 4.86 and $5.53 \mathrm{~km} / \mathrm{h}$ under different digging depths the highest power as a result of increasing the forward speed improved the soil mean diameter and the soil pulverization ratio and soil resistance. El-Raie (1982) explained that, when drawbar pull increased 
slip percentage increases. He advised that slip must be kept less than $15 \%$. If the amount exceeded it will cause a loss in power. Abd ElWahab (1994) showed that increases the forward speed increasing in slip, draft and consumed energy. A fast-growing summer annual, berseem crop can produce up to $8 \mathrm{Mg}$ of forage under irrigation (Clark et al., 2007). Therefore, this research aims to improve seedbed for clover seed germination by adding till shares at the front of the land leveler blade.

\section{MATERIALS AND METHODS}

This study carried out in a local farm at El-Snbellaween district, Dakahlia Governorate after harvesting rice. To achieve study aim the following subjects were identified;

1- Connecting the land leveler with shares.

2- Evaluate the performance of developed land leveler and comparing it with traditional leveler and no-till.

\section{Developed land leveler and share specifications}

Land leveler with $2200 \mathrm{~mm}$ working width, $700 \mathrm{~mm}$ length and $600 \mathrm{~mm}$ height is used as a minimum till of the soil. The shares bar added in the front of land leveler as shown in Fig. (1). A shovel type with $200 \mathrm{~mm}$ length and $60 \mathrm{~mm}$ wide were conducted and controlled with shares bar.

\section{Source of power}

The Romanian tractor (Universal $650 \mathrm{M}$ ) model, rated at $48.5 \mathrm{~kW}(65 \mathrm{hp}$ ) and $540 \mathrm{rpm}$ is used in the all treatments.

\section{Soil properties}

The experiments were carried out in silty loam soil texture. The mechanical analysis and soil properties are tabulated in Table (1).I

Table 1: The soil mechanical analysis and son properties.

\begin{tabular}{|c|c|c|c|c|c|c|}
\hline $\begin{array}{c}\text { Depth of } \\
\text { sample }\end{array}$ & $\begin{array}{c}\text { Clay, } \\
\%\end{array}$ & $\begin{array}{c}\text { Silt, } \\
\%\end{array}$ & $\begin{array}{c}\text { Fine sand, } \\
\%\end{array}$ & $\begin{array}{c}\text { Coarse sand, } \\
\%\end{array}$ & $\begin{array}{c}\text { MC, } \\
\%\end{array}$ & $\begin{array}{c}\text { Bulk density, } \\
\mathrm{g} / \mathrm{cm}^{3}\end{array}$ \\
\hline $0-15 \mathrm{~cm}$ & 35 & 44 & 18.98 & 2.02 & 18.25 & 1.35 \\
\hline
\end{tabular}

\section{Experimental procedure}

Experimental area of about $19000 \mathrm{~m}^{2}$ was established as split-split plots in three replicates. This area divided into six main plots involved three share depths and three shares span. 

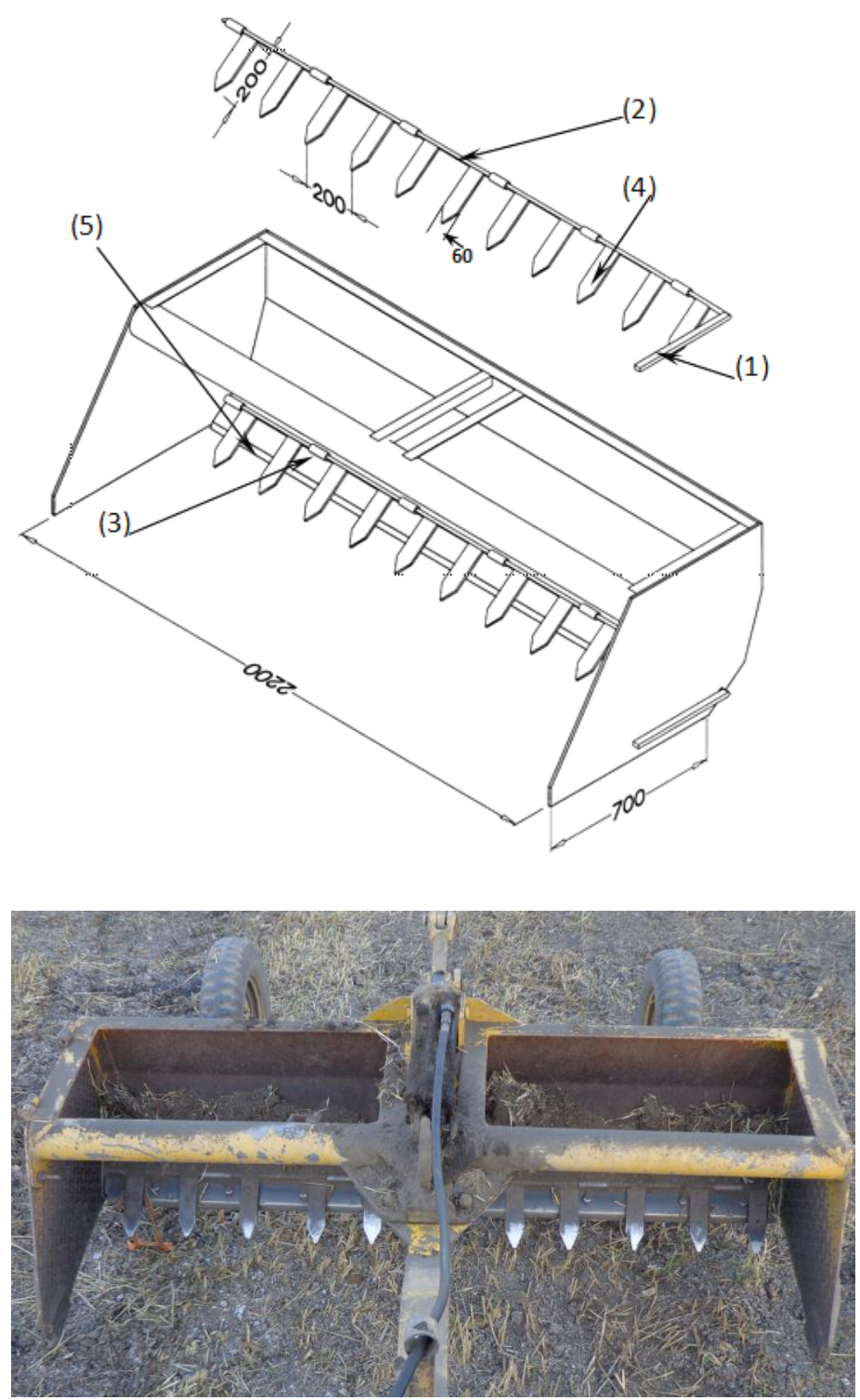

1- Shares lever arm 2- Shares carrier bar 3- Fixing and rotation joint 4- Shares 5- Cutting blade Fig. (1) The developed land leveler

Each main plot includes four sub-plots, which involved four forward speeds. Each sub-plots include three sub sub-plots which involved three replicates, resulted in a total of 84 plots, each of $220 \mathrm{~m}^{2}(2.2 \times 100 \mathrm{~m})$. The variable includes; three shares span of 118,154 and $200 \mathrm{~mm}$ with 18 , 
14 and 11 shares number respectively, share depths of 0,50 and $100 \mathrm{~mm}$ and forward speeds of 2.7, 3.7, 4.3 and $4.9 \mathrm{~km} . \mathrm{h}^{-1}$.

\section{Measurements}

\section{Soil mean weight diameter (MWD)}

The sieves apparatus was used to measure the cold-size distribution. That device consists of 6 square sieves located on top of each other, on wooden. The outer link of each sieve was $200 \mathrm{~mm}$, and the opining sizes were $100,80,60,40,20$ and $10 \mathrm{~mm}$. After sieving all the individual fractions are weighed and finally, all the portions calculated according to the following equation (Rnam, 1991):

$$
M W D=\sum^{n} x_{i} W_{i}
$$

Where:

MWD : Mean weight diameter, mm

$\mathrm{X}_{\mathrm{i}} \quad$ : Mean of measured diameters

$\mathrm{W}_{\mathrm{i}} \quad$ : Percent of weight samples on the sieves from total weight

Pulling force (P) a hydraulic dynamometer was mounted between two tractors. The land leveler is mounted on one and both were pulled by the another one (Fig. 2). Ten readings were recorded by the dynamometer at the different forward speed and the mean was calculated. Rolling resistance $\left(R_{R}\right)$ is the force required to pull both tractor and the land leveler when the shares is lifted. There fore, the $\left(\mathrm{N}_{\mathrm{p}}\right)$ net pull force is calculated as follows:

$$
N_{P}=P-R_{R}(k N) \text {. }
$$

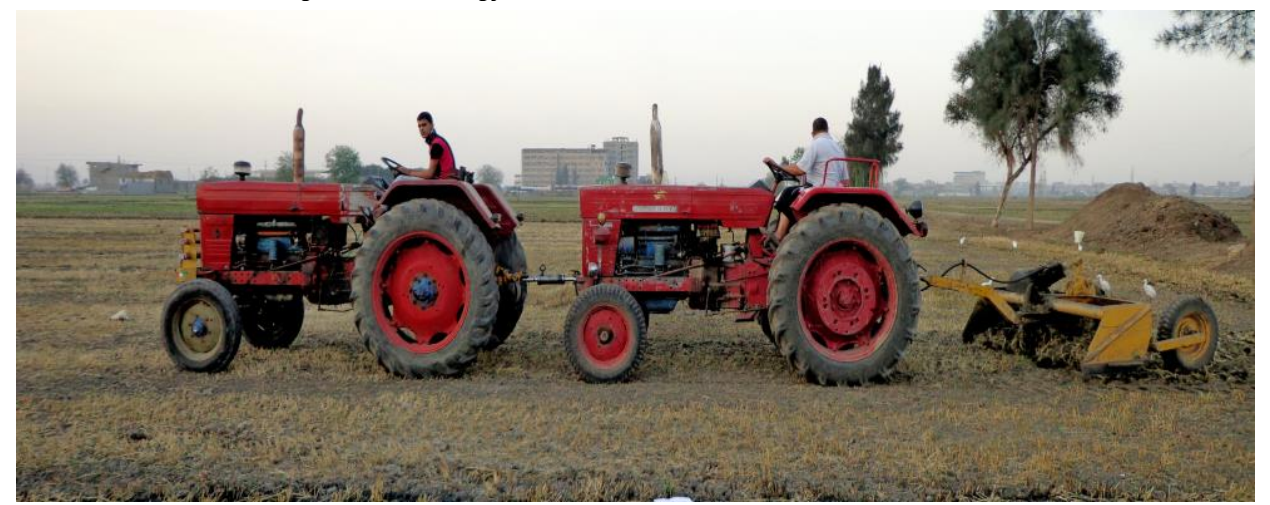

Fig. (2): Pulling force measurement

Slip (S), The tractor slip is calculated from the following equation: 


$$
S=\frac{V_{1}-V_{2}}{V_{1}} \times 100
$$

Where:

$\mathrm{S}=$ tractor slip, \%

$\mathrm{V}_{1}=$ forward speed without load, $\mathrm{km} / \mathrm{h}$

$\mathrm{V}_{2}=$ forward speed with load, $\mathrm{km} / \mathrm{h}$

The specific energy was calculated using equation (Barger et al., 1963):

$$
S_{e}=\left(\frac{F_{u} \times \rho_{f} \times C . V}{3600}\right) \times\left(\frac{427 \times \eta_{t h} \times \eta_{m}}{75 \times 1.36 \times F_{c}}\right) .
$$

\section{Where:}

$\mathrm{S}_{\mathrm{e}} \quad$ : specific energy, $(\mathrm{kW} \mathrm{h/fed)}$;

$\mathrm{F}_{\mathrm{u}}$ : fuel consumption rate, $(\mathrm{L} / \mathrm{h})$;

$\rho_{\mathrm{f}} \quad$ : density of fuel, $\mathrm{kg} / \mathrm{L}$, (for diesel $=0.85 \mathrm{~kg} / \mathrm{L}$ );

C.V : calorific value of fuel, $(\mathrm{kCal} / \mathrm{kg})$;

427 : thermal-mechanical equivalent, (kg.m/kCal);

$\eta_{\text {th }}:$ thermal efficiency of the engine, assumed $40 \%$ for diesel engine;

$\eta_{\mathrm{m}}$ : mechanical efficiency to engine, assumed $80 \%$ for diesel engine;

$\mathrm{F}_{\mathrm{c}} \quad$ : actual field capacity, fed/h.

Planting intensity $\left(\mathbf{N}_{\mathrm{o}} / \mathbf{m}^{2}\right)$ A wooden frame $(1 \times 1 \mathrm{~m})$ is randomizing setting for each treatment after 15 days from planting. It's easy to calculate the number per square meter (Cosgrove, 1996) after collect the numbers of plants in the wooden frame. The seeding rate in all treatment was $30 \mathrm{~kg} / \mathrm{fed}$ as recommended by Crop Institute Research.

\section{Uprooting rice root, \%}

After completing the operations service and using a wooden frame $(2 \times 2$ $\mathrm{m})$ a number of non-uprooted roots counting from randomizing setting per each treatment. After collect the number of non-uprooted roots in the wooden frame, it can calculate the uprooting rice root percentages from the following equation:

$$
U_{r}=\frac{T_{r}-N_{r}}{T_{r}} \times 100
$$


Where:

$\mathrm{U}_{\mathrm{r}}=$ Uprooting rice root, $\%$

$\mathrm{T}_{\mathrm{r}}=$ The total roots number before serving per each treatment,

$\mathrm{N}_{\mathrm{r}}=$ The non-uprooted roots number after serving per each treatment.

\section{RESULTS AND DISCUSSIONS}

\section{Clod-size-distribution (MWD)}

As shown in Fig. (3), it was clear that increasing forward speed resulted in decreasing mean weight diameter (MWD), mm but increasing share depths and shares span showed an increase in MWD, mm. While increasing shares span from 118 to $200 \mathrm{~mm}$ increasing the MWD from 27 to 44.5 and 44 to $60 \mathrm{~mm}$ respectively at share depths 50 and $100 \mathrm{~mm}$. Hence, from the same figure it can be seen that, increasing forward speed from 2.7 to $4.9 \mathrm{~km} / \mathrm{h}$ decreasing MWD from 44.00 to 28.67 and 62.33 to $41 \mathrm{~mm}$ respectively at share depths 50 and $100 \mathrm{~mm}$.

Also, from Fig. (4), it clear increasing share depths from 50 to $100 \mathrm{~mm}$ increased MWD by $32.10 \%$ and about $69.66 \%$. These results may be due to, increases the soil movement speed increasing the kinetic energy of the cutting soil slices and leads to more crumbling leads to decreasing the diameter of clod-size. On the other hand, increasing share depths leads to increases the thickness of the soil slices consequently increasing the diameter of clod-size.
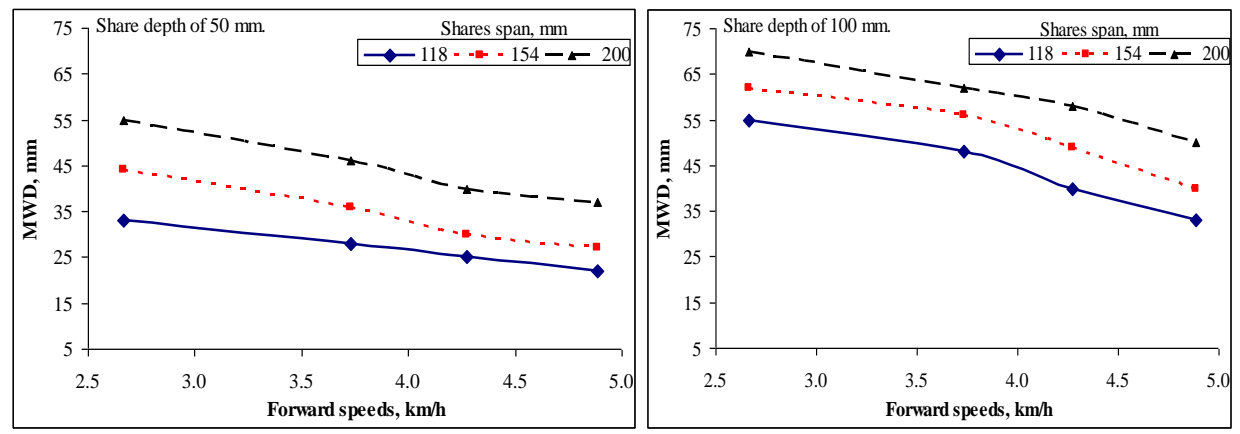

Fig. (3): Effect of forward speeds on MWD at different shares span and share depths 


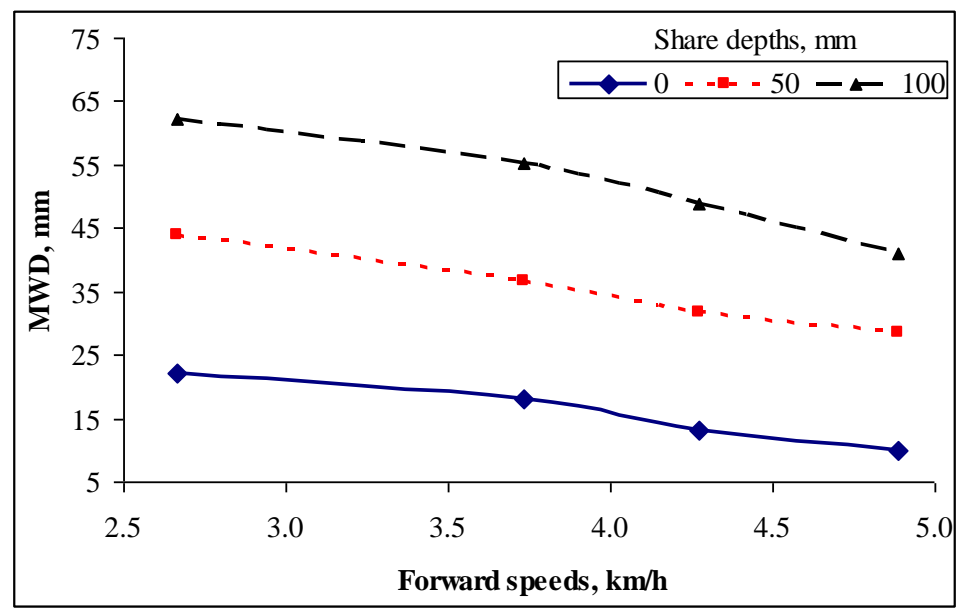

Fig. (4): Effect of forward speeds on MWD at different share depths

\section{The pulling force $(\mathrm{kN})$}

The pulling force of the developed land leveler as affected by the forward speed $(\mathrm{km} / \mathrm{h})$, shares span $(\mathrm{mm})$ and two share depths $(\mathrm{mm})$ is illustrated in Fig. (5). The pulling force required for land leveler were varying linearly with the forward speed. Fore example, the forward speed increased from 2.7 to $4.9 \mathrm{~km} / \mathrm{h}$ the pulling force increased by 37.16 and $33.51 \%$ at share depths $50,100 \mathrm{~mm}$ respectively and at the different shares span.
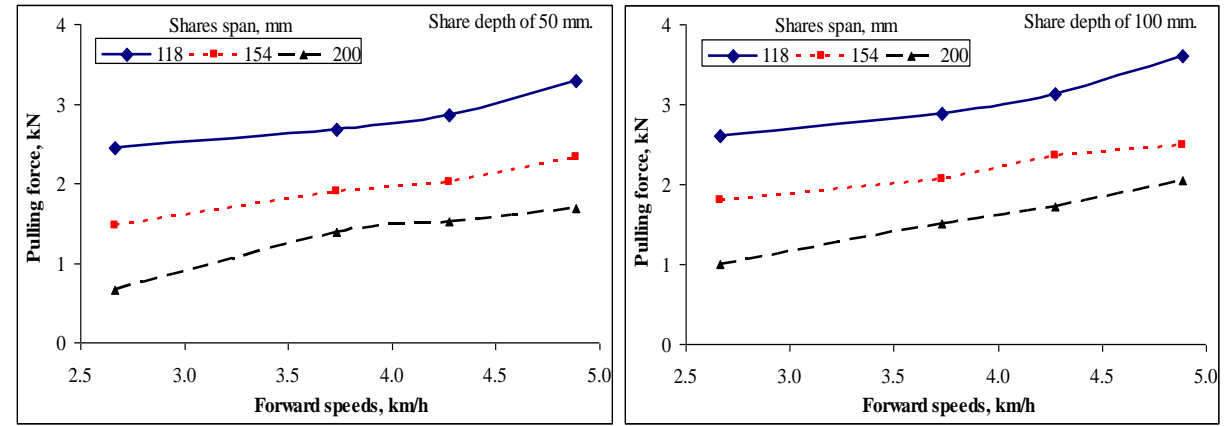

Fig. (5) Effect of forward speeds on pulling force at different shares span and share depths

Also from in Fig. (6) the required pulling force required were varying with the share depths. As the share depths increased from 50 to $100 \mathrm{~mm}$ the required pulling force increased by $11.5 \%$. This may be due to that, increasing both of share depths and forward speed, leads to more of soil resistance which needed more of pulling requirement. 


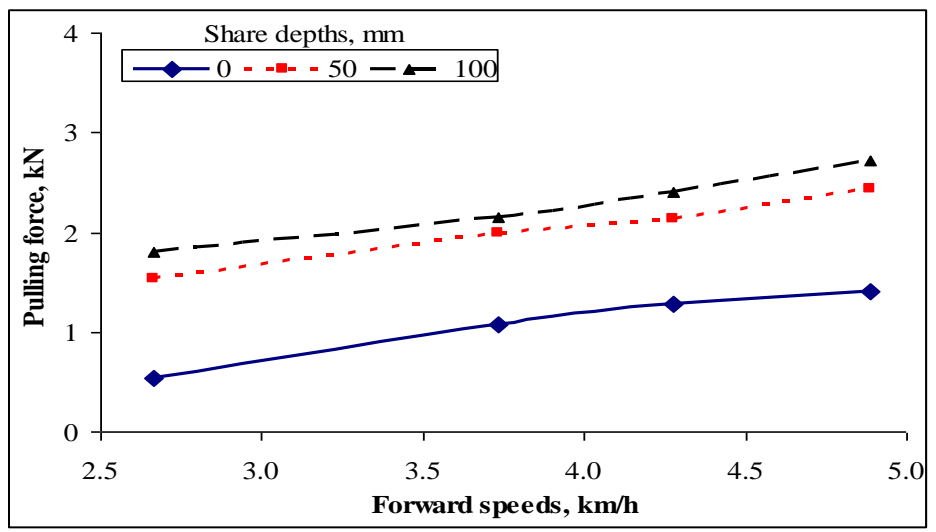

Fig. (6) Effect of forward speeds on pulling force at different share depths.

\section{Tractor wheel slip}

The slip data are presented at four different forward speeds, three shares span and two share depths. The average slip data are shown in Figs. (7 and 8)
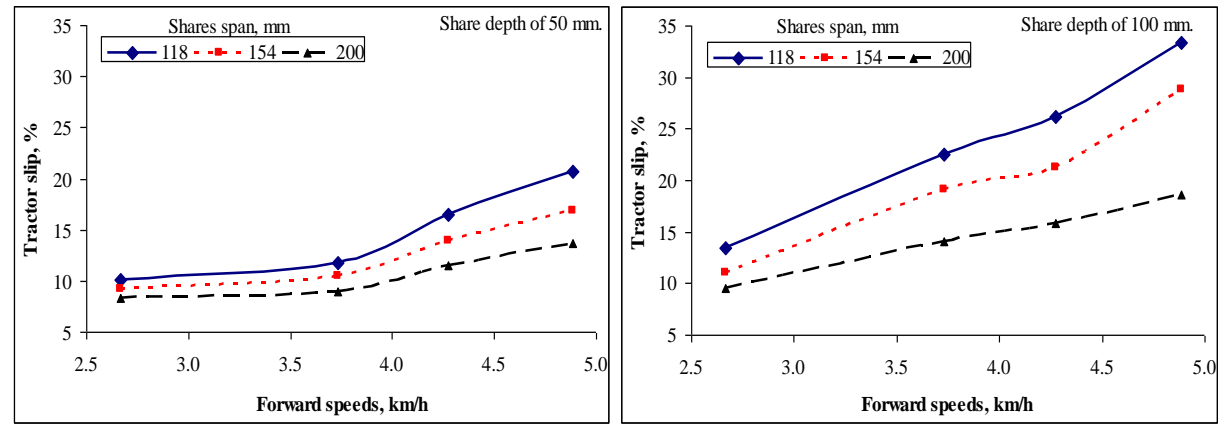

Fig. (7) Effect of forward speeds on tractor slip at different shares span and share depths.

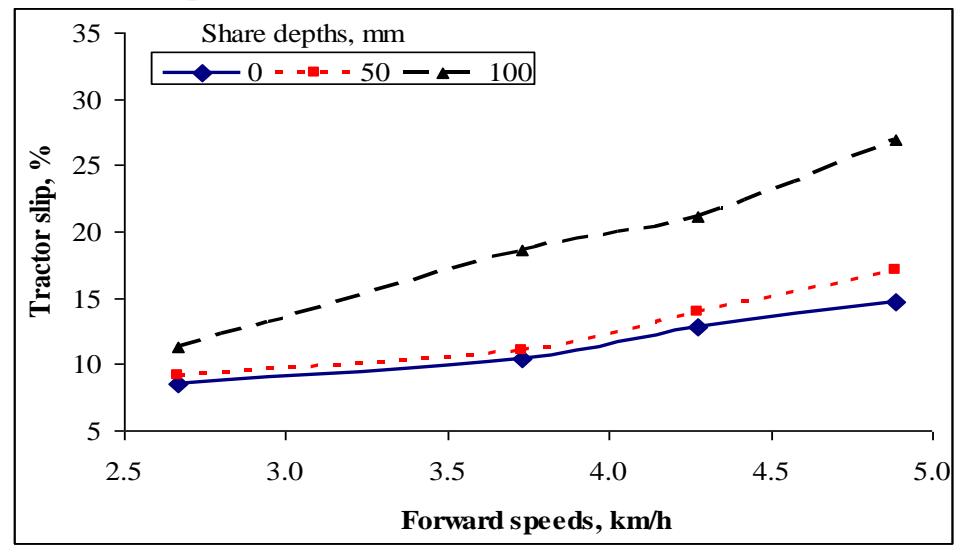

Fig. (8) Effect of forward speeds on tractor slip at different share depths. 
It can be seen that, increasing forward speed gave a sensible increment rates in slip, \%. For example, slip, \% increased from 9.19 to 17.07 and from 11.32 to $26.93 \%$ as the forward speed increased from 2.7 to 4.9 $(\mathrm{km} / \mathrm{h})$ at share depths of $50,100 \mathrm{~mm}$ respectively. While increasing shares span from 118 to $200 \mathrm{~mm}$ decreased slip, \% from 14.7 to $10.6 \%$ and from 23.87 to $12.54 \%$ at share depths $50,100 \mathrm{~mm}$ respectively. Also, Fig. (8) indicated that, increasing share depths from 50 to $100 \mathrm{~mm}$ the tractor slip, \% increased by $34.92 \%$. Owing the slippage should be less than $15 \%$ for the combination of the tractors. So, the suitable forward speed for the tractor may be ranged from 2.7 to $3.7 \mathrm{~km} / \mathrm{h}$.

\section{Specific energy}

As shown in Fig. (9) by increasing forward speed and shares span resulted in decreasing specific energy $\mathrm{kW} \mathrm{h/fed,} \mathrm{but} \mathrm{increasing} \mathrm{share} \mathrm{depths}$ showed an increase in specific energy. Increasing shares span from 118 to $200 \mathrm{~mm}$ decreasing the specific energy from 11.79 to 10.55 and 12.79 to $10.87 \mathrm{~kW} \mathrm{h/fed} \mathrm{respectively} \mathrm{at} \mathrm{share} \mathrm{depths} 50$ and $100 \mathrm{~mm}$, at stability forward speed. Hence, from the figure, increasing forward speed from 2.7 to $4.9 \mathrm{~km} / \mathrm{h}$ decreasing specific energy from 12.29 to 10.16 and 12.9 to $11.78 \mathrm{~kW} \mathrm{h/fed} \mathrm{respectively} \mathrm{at} \mathrm{share} \mathrm{depths} 50$ and $100 \mathrm{~mm}$ at neglected the effect of shares span.
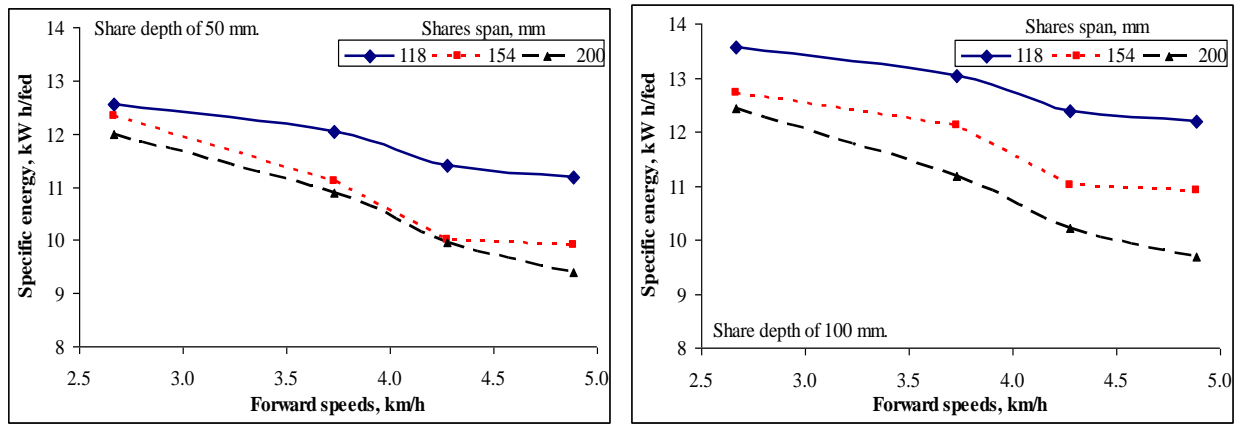

Fig. (9) Effect of forward speeds on specific energy at different shares span and share depths.

Also, in Fig. (10) increasing share depths from 50 to $100 \mathrm{~mm}$ increasing specific energy by $6.13 \%$ and about $16.18 \%$ at increase the share depths from 0.0 to $100.0 \mathrm{~mm}$, at neglected the effect of other factor. These results may be due to, increasing share depths and reducing shares span leads to more power consumed to soil resistance. 


\section{Planting intensity:}

Planting intensity is the important growth indicator for high yield. Therefore, it was taking to evaluate the operating parameters of this study, which were forward speed $(\mathrm{km} / \mathrm{h})$, shares span $(\mathrm{mm})$ and two share depths $(\mathrm{mm})$. The determined data are shown in Fig. (11). From the figure, the intensity percent is always higher in favor of the forward speed between 2.7 to $3.7 \mathrm{~km} / \mathrm{h}$. From Fig. (11), it should denoted that the maximum obtained planting intensity was $635 \mathrm{plant} / \mathrm{m}^{2}$, at share depth $50 \mathrm{~mm}$, shares span $118 \mathrm{~mm}$ and forward speed of $3.7 \mathrm{~km} / \mathrm{h}$, while the corresponding data at share depth $100 \mathrm{~mm}$ was $520 \mathrm{plant} / \mathrm{m}^{2}$ by decrement of $18.11 \%$.

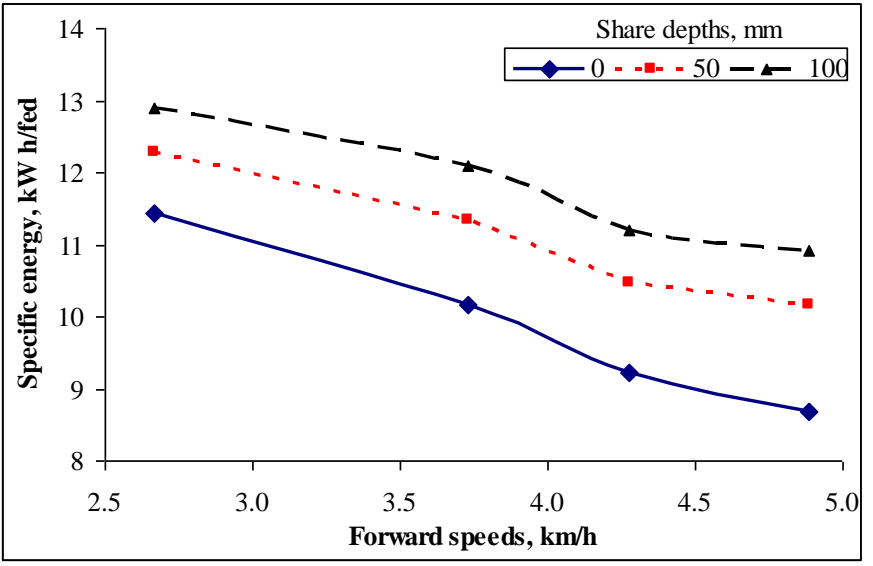

Fig. (10) Effect of forward speeds on specific energy at different share depths.
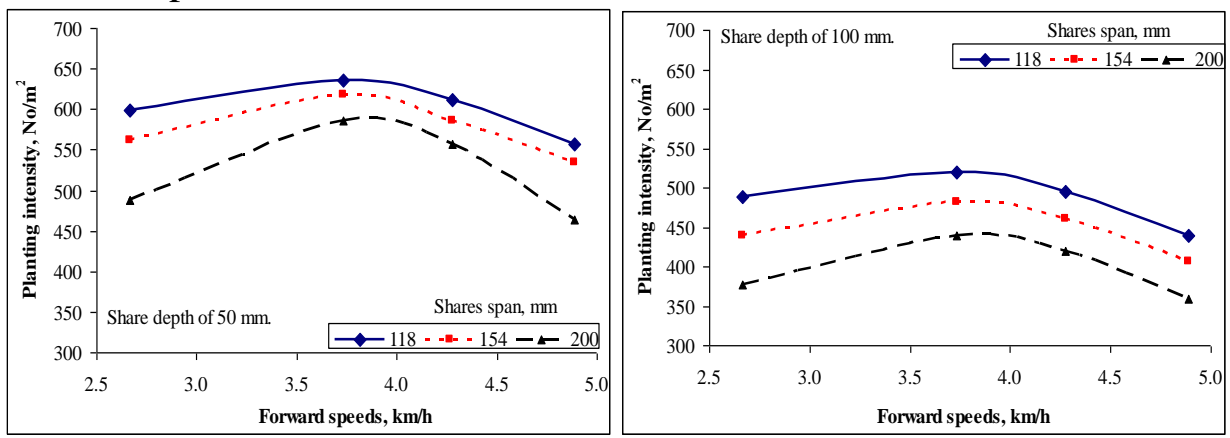

Fig. (11) Effect of forward speeds on planting intensity at different shares span and share depths.

On the other hand, increasing shares span from 118 to $200 \mathrm{~mm}$ decreasing the planting intensity by $15.07 \%$. From the Fig. (12) and if comparison 
was done between using shares and blade it noticed that using shares increasing planting intensity by 25.38 and $3.73 \%$ at shares span of 118 and $200 \mathrm{~mm}$, respectively.

Finally, from the viewpoint of planting intensity it may be recommended that using shares span $118 \mathrm{~mm}$, share depth of $50 \mathrm{~mm}$ and forward speed of $3.7 \mathrm{~km} / \mathrm{h}$, due to good pulverization and good soil structure suite to clover plant germination.

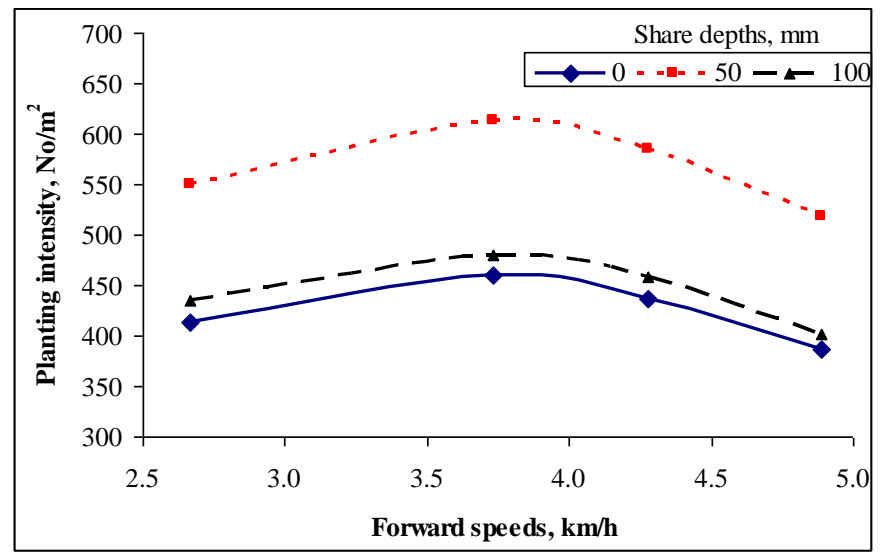

Fig. (12) Effect forward speeds on planting intensity at different share depths.

\section{Uprooting rice root:}

As indicated before rice roots leads to a significant obstruction to the farmer's sickle at the first cutting of clover. So removing those roots is important factor for evaluating this study. The uprooting process was evaluated as affected by forward speed $(\mathrm{km} / \mathrm{h})$, shares span $(\mathrm{mm})$ and two share depths (mm). The determined data are shown in Figs. (13 and 14). From these figures, it easily noticed that the uprooting percent is always lower in favor of the share depth of $50 \mathrm{~mm}$. On the other hand, the uprooting percent increased with a higher rate as the speed increased from 2.7 to 3.7 at the two share depths. From Fig. (13) the maximum obtained uprooting percent was $95 \%$, at share depth $100 \mathrm{~mm}$, forward speed of 3.7 $\mathrm{km} / \mathrm{h}$ and shares span of $118 \mathrm{~mm}$. while the corresponding data at share depth $50 \mathrm{~mm}$ was $79 \%$ by decrement of $16.8 \%$.

On the other hand, increasing shares span from 118 to $200 \mathrm{~mm}$ decreasing the uprooting percent by $19.75 \%$ when neglecting the effect of the other factor study. 

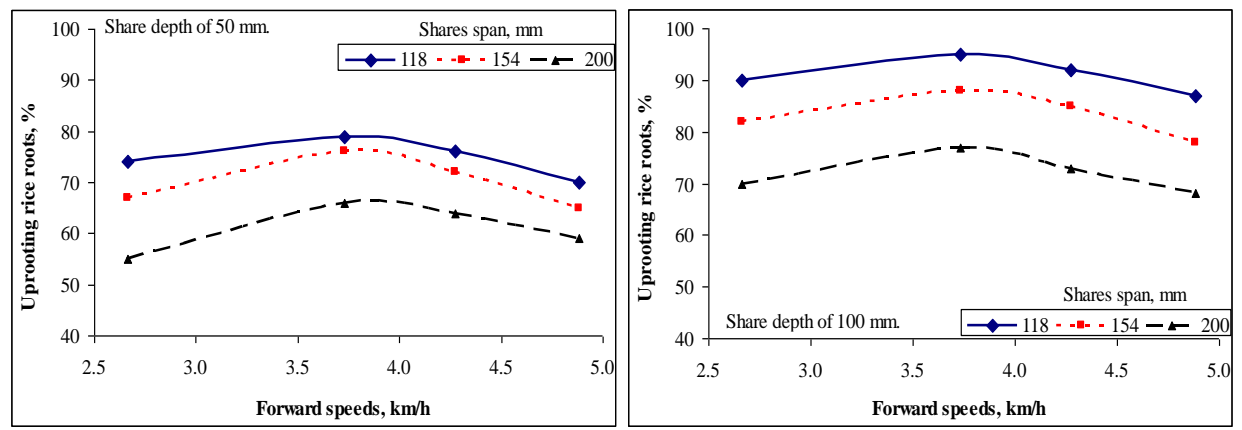

Fig. (13) Effect of forward speeds on uprooting rice roots at different shares span and share depths.

From the Fig. (14), if a comparison was done between using shares and blade noticed that using shares increasing uprooting rice roots by 47.14 and $55.83 \%$ at share depths of 50 and $100 \mathrm{~mm}$, respectively.

Finally, from the viewpoint of uprooting percent it may be recommended that using speed range from 2.7 to $3.7 \mathrm{~km} / \mathrm{h}$, shares span $118 \mathrm{~mm}$ and share depth of $100 \mathrm{~mm}$ to achieve the highest proportion of uprooting root rice.

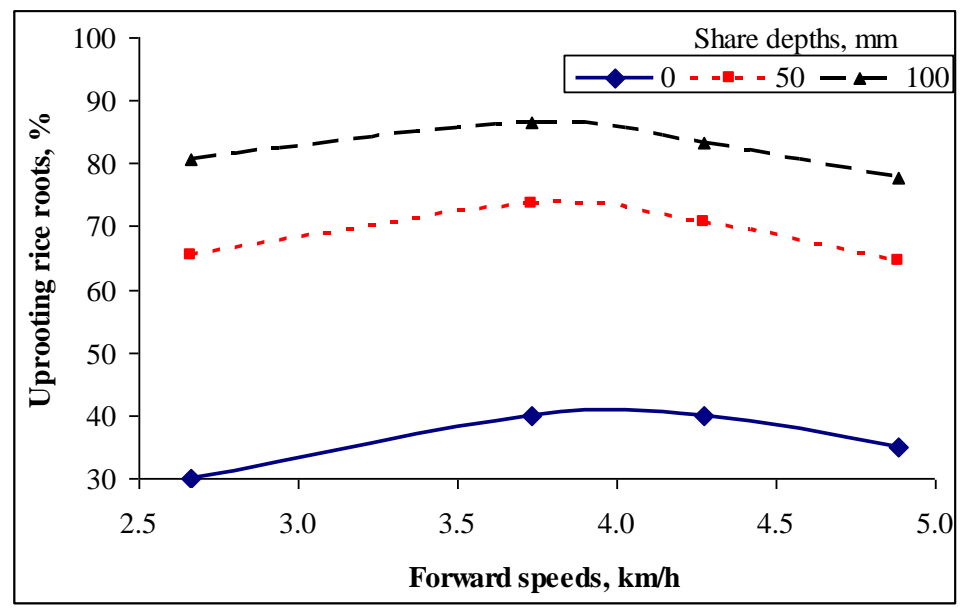

Fig. (14) Effect of forward speeds on uprooting rice roots at different share depths.

\section{Clover yield}

Yield is the important aim of this study so the average yield data for clover yield are shown in Fig. (15). From the figure, it can be easily seen that, going deeply into cutting time exhibited in general a randomized increasing clover yield. For example from the first to fourth clover cutting 
increased clover yield by $13.11 \%$. That by reason roots growth and increasing root nodules (Rhyzobium) which leads to increasing yield. The clover yield increase about 20.49 and $16.47 \%$ at share depths of 50 and $100 \mathrm{~mm}$ respectively compared with share depth $0.0 \mathrm{~mm}$. While, if comparison was done between the two using share depths 50 and $100 \mathrm{~mm}$ it can be seen that increasing share depths from 50 to $100 \mathrm{~mm}$ decreasing clover yield by $4.33 \%$.

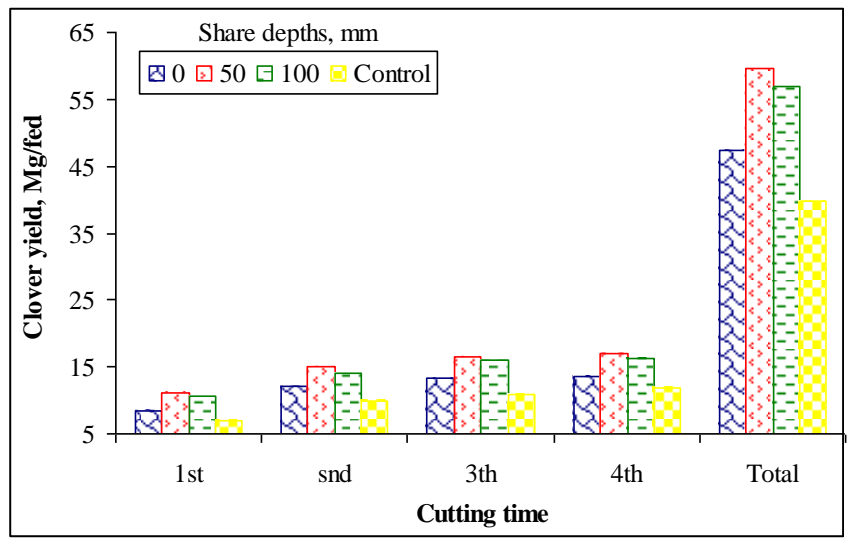

Fig. (15) The relationship between clover yield and cutting time at different share depths.

Finally, from the viewpoint of clover yield it may be recommended that using share depth of $50 \mathrm{~mm}$.

\section{CONCLUSIONS}

After proceeding this research and to obtained maximum yield, it is recommended that using land leveler with share at forward speed range from 2.7 to $3.7 \mathrm{~km} / \mathrm{h}$, shares span $118 \mathrm{~mm}$ and share depth of $50 \mathrm{~mm}$ to get a suitable seedbed.

\section{REFERENCES}

Abd El-Wahab, M.K. (1994). Minimum tillage by a simple combination. Miss J. Agric. Eng., 11 (3): 711-724.

Abou Habaga, M.M. (1992). Influence of soil colds size distribution in seed bed on the applicability of a grain drill machine for wheat. Misr. J. Agric. Eng. 9 (1): 58-66. 
Abou Habaga, M.M. (2000).Effect of center pivot wheel on soil compaction and crop yield. J. Agric. Sci. Mansoura Univ., 25 (10): 6433-6438.

Clark, A.E. (2007). Managing Cover Crops Profitably, $3^{\text {rd }}$ Ed. Sustainable Agriculture Network, Beltsville, MD.

Cook, R.L. and F.W. Peikert (1960). A comparison of tillage implements. Trans. of ASAE, 31: p. 221-214.

Cosgrove, D. (1996). Alfalfa Management Guide. University of WisconsinRiver Falls, pp: 1-68.

El-Raie, A.S. (1982). Agricultural tractors. Training programs, Part 14, Ministry of Agriculture, Egypt. Pp 434.

El-Sayed, A.S., A.A. Abdel-Razek and M.M. El-Menoufi (1988). Effect of different tillage practices upon soil properties and wheat yield Misr J. Agric. Eng. 5(3): 282-296.

Mahrous, F.N.; A.Y. Badawi ; M.N. Seif El-Yazal; H.W. Tawadros and A. Serry (1984). Effect of soil moisture on Egyptian clover. Agric. Res. Rev. 62(4A): 39-50.

Michael, K.M. (1990). Effect of leveling on the performance of some farm machinery. Ph.D. Thesis, Fac. of Agric., Moshtohor, Zagazig Univ., Egypt.

Ministry of Agriculture and Land Reclamation Economic Affalrs Sector (EAS) (2012). Study of the indicators agricultural statistics. 86.

Rickman, J.F. (2002). Manual for laser land leveling, Rice-wheat Consortium Technical Bulletin Series 5. New Delhi-12, India: Ricewheat Consortium for the Indo-Gangetic Plains. pp. 24.

Rnam (Regional Network for Agricultural Machinery) (1991). Agricultural machinery design and data handbook. Economic and Social Commission for Asia and the pacific.

Zayed, M.F. (2010). Development of laser land leveling system. PhD. Thesis. Agric. Eng. Dept., Fac. of Agric., Mansoura University. 


\section{الملخص العربيى}

\section{تطوير القصابية لتلائم تهيئة التربة لمحصول البرسيم

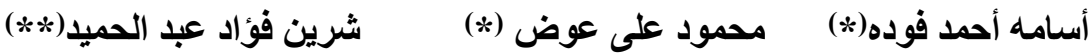

يعتبر البرسيم المحصول الأول كعلف أخضر للحيوان في مصر وتبلغ المسـاحة المنزر عـة بـه حو الي

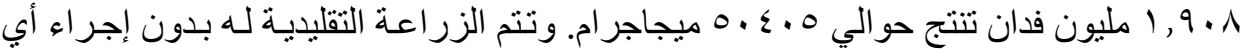

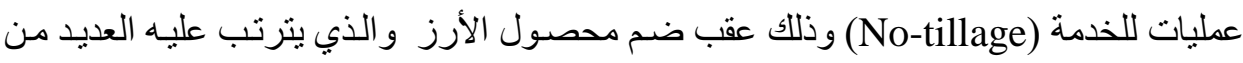
المشكلات أهمها:

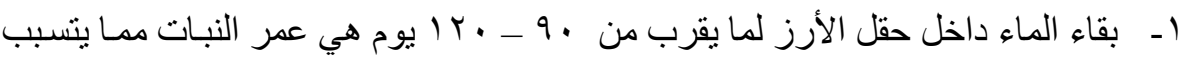

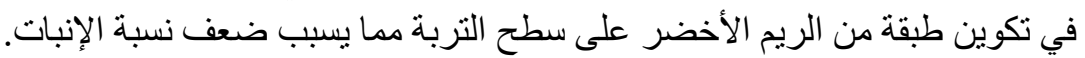

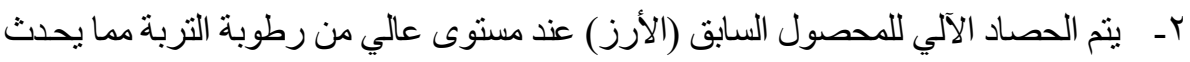

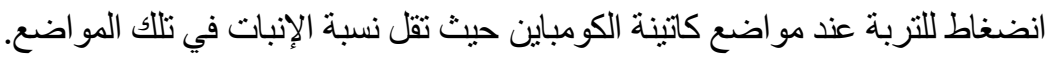

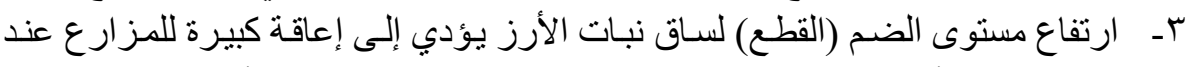

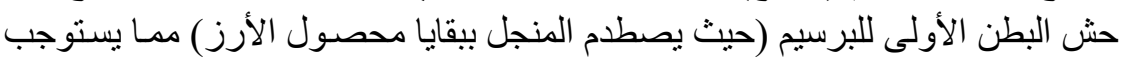
التخلص من تلك البقايا. لذا يهدف البحث إلى تطوير القصابية بتزويدها بشفرات أشبة ما يكون بأسلحة صغيرة على شكل لسان

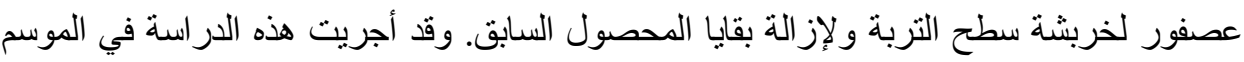

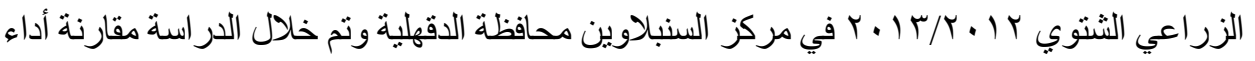

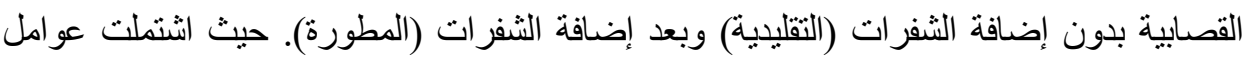

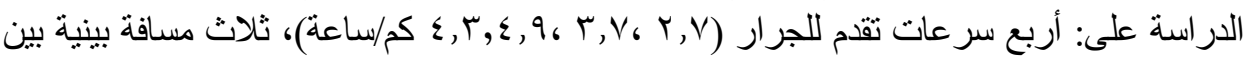

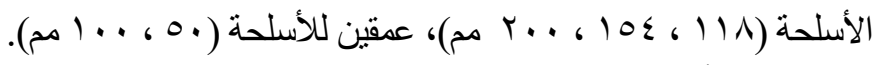

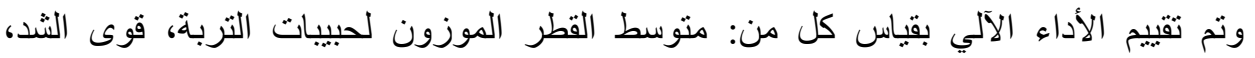

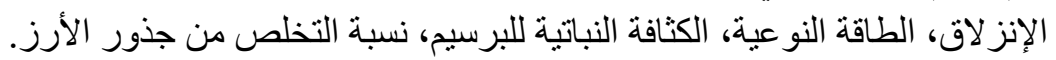
وكانت أهم النتائج المتحصل عليها زاد كلا من نسبة اقتاعلاع بقايا جذور الأرز وكذا الكثافة النباتية

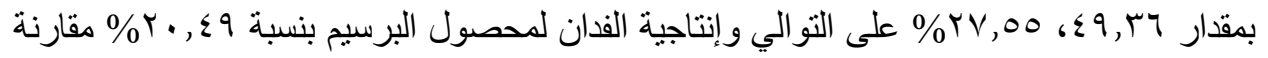

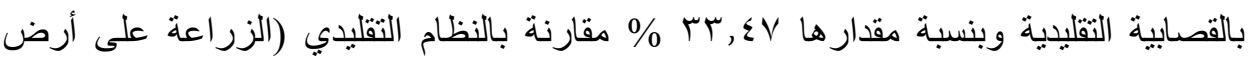

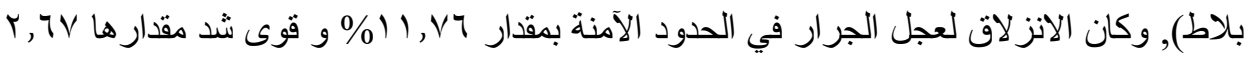

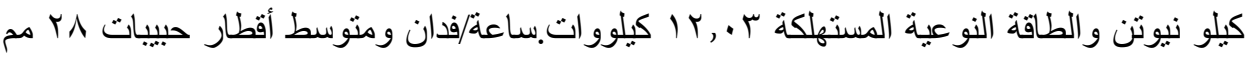

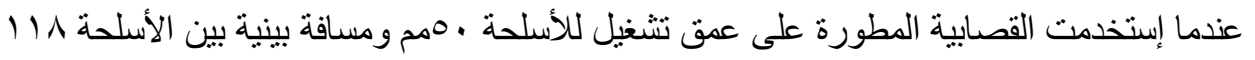
مم وسر عة أمامية V, T كم/ساعة.

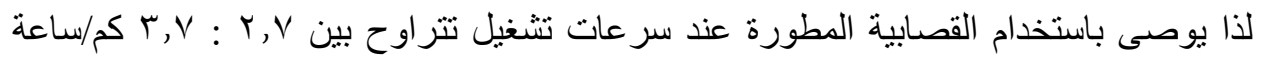

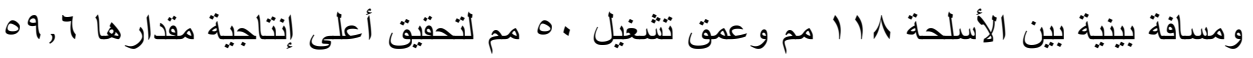
ميجاجر ام/فدان من مجموع أربع حشّات.

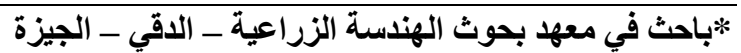

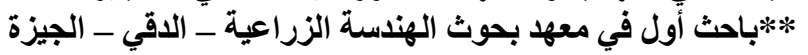

